\title{
Medication Safety in the Operating Room: Teaming Up to Improve Patient Safety
}

Rozina Merali, Beverley A. Orser, Alexandra Leeksma, Shirley Lingard, Susan Belo and Sylvia Hyland

\begin{abstract}
A medication safety project for operating rooms (ORs) was initiated under the leadership of the Departments of Anesthesia and Nursing with a representative from the Canadian Anesthesiologists' Society and the Institute for Safe Medication Practices Canada. The aims of the collaborative project were twofold: (1) to identify areas of exposure to risk and make recommendations to enhance medication safety within the hospital and (2) to inform the development of a medication safety checklist specific to the OR setting. The strategies developed and implemented during this project were aimed at reducing the risk of injury induced by medications. Attempts were made to use feasible best practices and managerial support systems for defined areas - in this case, medication-use systems for the ORs and associated patient care areas. The learning from this project will also inform the development of a medication safety checklist for use by other hospitals and OR settings.
\end{abstract}

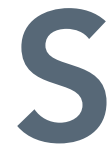
everal studies have suggested that medication error is a leading cause of adverse events during anesthesia. For example, in an analysis of critical events during anesthesia, Cooper et al. (1984) demonstrated that the total number of medication-related events (including syringe swaps, drug ampoule swaps, overdoses and incorrect drug choices) far exceeded the next most frequent problem, disconnection of the breathing circuit. In a large Australian survey, Webster et al. (2001) estimated the incidence of drug administration errors in anesthesia on the basis of a large, prospective set of data. Overall, one drug administration error was reported for every 133 anesthetics administered. A survey of 687 anesthesiologists (representing a 30\% response rate) (Orser et al. 2001) revealed that $85 \%$ of the respondents had experienced at least one drug error or near miss. A variety of factors contribute to increases in the risk of medication error in patients undergoing anesthesia, including the use of potent drugs that carry a risk of serious injury or death when administered in excessive doses or without adequate patient support; the dynamic, complex environment of the operating suite; and the fact that one person is responsible for prescribing, dispensing and administering the anesthetic and 
monitoring the patient. Safeguards that are present in hospital nursing units (e.g., review of medication orders by nurses or pharmacists) are lacking. In addition, the administration of several high-risk drugs over a short period of time likely increases the likelihood of errors (Orser 2000).

\section{The Project}

In January 2005, patient safety was adopted as a priority for a large teaching hospital in Ontario. The hospital's board of trustees approved an Accountability for Patient Safety Policy, which created a framework for all staff, volunteers and physicians, emphasizing shared responsibility to ensure that systems of care were as safe as possible.

A medication safety project for operating rooms (ORs) was initiated under the leadership of the Departments of Anesthesia and Nursing. The Institute for Safe Medication Practices Canada (ISMP Canada) was invited to be a team member. The aims of the collaborative project were twofold: (1) to identify areas of exposure to risk and make recommendations to enhance medication safety within the hospital and (2) to inform the development of a medication safety self-assessment specific to the OR setting and related patient care areas, as part of a collaborative project with the Canadian Anesthesiologists' Society. The project was funded through the Ontario Ministry of Health and Long-Term Care.

On March 15 and 16, 2005, an interdisciplinary team of consultants from ISMP Canada, along with a representative from the US-based ISMP, performed a targeted system review of medication use in the OR and related patient care areas at the hospital. The review team observed the environments in which medications were prescribed, stored, transcribed, prepared, dispensed and administered. Areas of direct observations included the same-day surgical ward, individual ORs and the post-anesthesia care unit. Physicians (surgeons and anesthesiologists), nurses, respiratory therapists, perfusionists, pharmacy technicians, educators and representatives from

Table 1. Examples of findings and recommendations of the review team

\begin{tabular}{|c|c|c|}
\hline Finding & Recommendation & Status of Change \\
\hline \multicolumn{3}{|l|}{ Patient Information } \\
\hline $\begin{array}{l}\text { Incomplete and inconsistent medication } \\
\text { history in patient charts } \\
\text { Lack of sufficient prompts to ensure } \\
\text { routine assessment of allergy } \\
\text { information }\end{array}$ & $\begin{array}{l}\text { Consistently document and complete preoperative } \\
\text { medication history for all patients } \\
\text { Add prompts to pre-admission records }\end{array}$ & $\begin{array}{l}\text { New forms to prompt for medication and allergy } \\
\text { history have been instituted. } \\
\text { Medication reconciliation initiative has been started } \\
\text { in associated patient care areas. }\end{array}$ \\
\hline \multicolumn{3}{|l|}{ Drug Information } \\
\hline $\begin{array}{l}\text { Pharmaceutical care not provided } \\
\text { routinely in OR, PACU and SDS areas }\end{array}$ & Provide enhanced pharmacist support & $\begin{array}{l}\text { Approval has been granted for one permanent full- } \\
\text { time equivalent pharmacist for the OR, PACU and } \\
\text { SDS areas. }\end{array}$ \\
\hline \multicolumn{3}{|c|}{ Communication of Drug Orders and Information } \\
\hline $\begin{array}{l}\text { Large number of abbreviations used } \\
\text { on preprinted forms and in medication } \\
\text { communications (verbal and written) }\end{array}$ & $\begin{array}{l}\text { Eliminate use of dangerous abbreviations and dose } \\
\text { expressions }\end{array}$ & Revisions have been made to preprinted forms. \\
\hline $\begin{array}{l}\text { Dose, frequency and route information } \\
\text { inconsistently written on handwritten } \\
\text { and preprinted orders }\end{array}$ & $\begin{array}{l}\text { Incorporate computerized physician order entry into } \\
\text { strategic planning }\end{array}$ & $\begin{array}{l}\text { Computerized physician order entry, integrated with } \\
\text { clinical decision support, is planned. }\end{array}$ \\
\hline \multicolumn{3}{|c|}{ Drug Labelling, Packaging and Nomenclature } \\
\hline $\begin{array}{l}\text { Medication brands change without } \\
\text { the knowledge of surgical teams or } \\
\text { technicians }\end{array}$ & Enhance communication mechanisms & This is currently in progress. \\
\hline $\begin{array}{l}\text { Anesthetic cart trays not standardized; } \\
\text { quantities not based on usage patterns }\end{array}$ & $\begin{array}{l}\text { Standardize anesthetic cart trays and consider usage } \\
\text { patterns }\end{array}$ & This has been completed. \\
\hline $\begin{array}{l}\text { Practitioner-prepared solutions, basins } \\
\text { and syringes are inconsistently labelled, } \\
\text { both on and off the sterile field }\end{array}$ & $\begin{array}{l}\text { Require labelling of all medications and solutions up } \\
\text { to the point of use } \\
\text { Standardize labelling procedures }\end{array}$ & $\begin{array}{l}\text { Policy, checklists and standardization of labelling are } \\
\text { in development. }\end{array}$ \\
\hline
\end{tabular}




\begin{tabular}{|c|c|c|}
\hline Finding & Recommendation & Status of Change \\
\hline \multicolumn{3}{|c|}{ Drug Standardization, Storage and Distribution } \\
\hline $\begin{array}{l}\text { Hazardous chemicals found in close } \\
\text { proximity to products designated for } \\
\text { patient use }\end{array}$ & $\begin{array}{l}\text { Evaluate need for, and then clearly identify and } \\
\text { segregate, hazardous products }\end{array}$ & This has been completed. \\
\hline $\begin{array}{l}\text { Selected medications prepared in the } \\
\text { unit with limited checking and sterility } \\
\text { safeguards }\end{array}$ & Increase provision of premixed solutions & $\begin{array}{l}\text { Opioids for epidural administration are now prepared } \\
\text { by pharmacy; additional medications are under } \\
\text { consideration for premixing. }\end{array}$ \\
\hline $\begin{array}{l}\text { Neuromuscular blocking agents not } \\
\text { adequately segregated in storage areas }\end{array}$ & $\begin{array}{l}\text { Segregate and label storage areas for neuromuscular } \\
\text { blockers }\end{array}$ & This has been completed. \\
\hline $\begin{array}{l}\text { Use of bulk bottles for medication } \\
\text { supplies, poor design of medication } \\
\text { supply area, incomplete documentation }\end{array}$ & $\begin{array}{l}\text { Budget for increased use of unit-dose products; } \\
\text { consider acquisition of profiled automated dispensing } \\
\text { cabinets for OR, PACU and SDS; incorporate bar- } \\
\text { coding into strategic planning }\end{array}$ & $\begin{array}{l}\text { One automated dispensing cabinet has been } \\
\text { installed, and its evaluation is in progress. }\end{array}$ \\
\hline \multicolumn{3}{|l|}{ Environment and Workflow } \\
\hline Top of anesthesia carts cluttered & $\begin{array}{l}\text { Minimize advance preparation of syringes for } \\
\text { later administration and segregate them from the } \\
\text { immediate workspace } \\
\text { Return or remove unused medications from the work } \\
\text { cart }\end{array}$ & $\begin{array}{l}\text { Ongoing monitoring of the environment has been } \\
\text { implemented. }\end{array}$ \\
\hline \multicolumn{3}{|l|}{ Staff Competency and Education } \\
\hline $\begin{array}{l}\text { Medication "stashes" found in selected } \\
\text { areas; other "workarounds" identified }\end{array}$ & $\begin{array}{l}\text { Investigate, evaluate and educate staff about the } \\
\text { dangers associated with workaround practices }\end{array}$ & Systems for review of practices are being explored. \\
\hline \multicolumn{3}{|l|}{ Patient Education } \\
\hline $\begin{array}{l}\text { Inconsistent preoperative teaching of } \\
\text { patients }\end{array}$ & $\begin{array}{l}\text { Provide enhanced education materials for } \\
\text { preoperative patients } \\
\text { Consider pharmacy involvement in same-day } \\
\text { assessment }\end{array}$ & These enhancements are in progress. \\
\hline \multicolumn{3}{|c|}{ Quality Processes and Risk Management } \\
\hline $\begin{array}{l}\text { Limited voluntary reporting, a "siloed" } \\
\text { error-analysis process and limited } \\
\text { feedback }\end{array}$ & $\begin{array}{l}\text { Encourage reporting (including near misses) by all } \\
\text { practitioners } \\
\text { Consider monitoring use of trigger drugs (e.g., } \\
\text { naloxone and other reversal agents) }\end{array}$ & $\begin{array}{l}\text { Hospital-wide electronic incident reporting program } \\
\text { is being implemented. } \\
\text { Patient safety rounds are held regularly. }\end{array}$ \\
\hline Inconsistent system of double-checks & $\begin{array}{l}\text { Consistently employ independent double-checks for } \\
\text { hospital-selected "high-alert" drugs }\end{array}$ & $\begin{array}{l}\text { Checklist development for high-risk procedures and } \\
\text { disease management is currently under review by } \\
\text { several departments. }\end{array}$ \\
\hline
\end{tabular}

PACU = post-anesthesia care unit; SDS = same-day surgery.

surgical management were interviewed. The team also toured the pharmacy. Various supporting documents (e.g., protocols, policies, procedures, order sets, drug guidelines, error reports and educational materials) were reviewed during the assessment process. System weaknesses were identified, and 75 specific recommendations were made to enhance medication safety.

Hospital managers reviewed and endorsed the recommendations (examples of which are listed in Table 1), and the Pharmacy
Department received funding to hire an OR pharmacist to lead the implementation of the recommendations. Deliverables for this pharmacist included developing an implementation team, leading the implementation of selected recommendations over the short term and helping to develop plans for the implementation of selected long-term recommendations. Many of the changes that have already been made or are currently in progress are being considered for hospital-wide implementation. 


\section{Discussion}

Published analyses of the underlying causes of medication errors suggest that many of these errors stem from basic ergonomic flaws in medication systems and the hospital environment (Leape et al. 1991; Silver and Antonow 2000). Systems approaches to deal with these ergonomic flaws and to thus reduce or intercept medication errors encompass standardization, simplification, the institution of double-check systems, restriction of access, the reduction of the reliance on memory and the creation of redundancies for critical functions. Incorporation of these principles into the design of work processes reduces the likelihood of error and increases the chances that any errors that do occur will be intercepted before patient harm occurs (Massachusetts Hospital Association 1999).

The teaching hospital that undertook this project recognized a need to address safety issues and to expand the knowledge base on medication safety. Although the efficacy of the recommendations in Table 1 has not yet been proven by formal research, it has been argued that many medication safety practices involve common sense and are well supported by human-factors literature in other industries (Leape et al. 2002). As such, the medication safety team feels that their implementation is reasonable. The carefully constructed implementation plan and agenda, the provision of education sessions and the creation of ongoing opportunities for input from different professional groups helped move the initiative forward and ensured that this collaborative project would provide knowledge translation for hospital staff. Nonetheless, achieving continued steady improvement will depend on adequate resources being sustained over an extended period.

\section{Conclusions}

Enhancing working relationships among anesthesiologists, pharmacists and nurses is pivotal for safe medication practices in the OR setting. The strategies developed and implemented during this project were aimed at reducing the risk of injury induced by medication errors. Attempts were made to use feasible best practices and managerial support systems for enhanced medication-use systems in the ORs and associated patient care areas. The learning from this project will also inform the development of a medication safety checklist for use by other hospitals. $\mathbf{H Q}$

\section{About the Authors}

Rozina Merali, BScPhm, RPh, PharmD, is a pharmaceutical consultant for the DIPECHO Project, World Health Organization, Tajikistan. At the time this article was written, Ms. Merali was a pharmacy specialist for the OR Project at Sunnybrook and Women's College Health Sciences Centre, Toronto, Ontario.

Beverley A. Orser, MD, PhD, FRCPC, is the Canada Research chair in anesthesia and a professor of physiology and anesthesia at the University of Toronto, Toronto, Ontario.
Alexandra Leeksma, RN, CPN(c), MN, is manager of surgical services, the operating room and related clinical support services at Sunnybrook Health Sciences Centre.

Shirley Lingard, RN, BScN, CPN(c), is an advanced practice nurse/educator for the operating room and related clinical support services at Sunnybrook Health Sciences Centre.

Susan Belo, PhD, MD, FRCPC, is assistant professor of anesthesia and pharmacology at Sunnybrook Health Sciences Centre and the University of Toronto.

Sylvia Hyland, RPh, BScPhm, MHSc, is vice-president of the Institute for Safe Medication Practices Canada, Toronto, Ontario. You can reach Ms. Hyland at shyland@ismp-canada.org.

\section{Acknowledgements}

We gratefully acknowledge members of the interdisciplinary team of consultants who provided the targeted system review: Susan Paparella, RN, MSN, director of consulting services (and currently vice-president at ISMP [US]); and Alex Ho, MD, FRCPC, who is with the Department of Anesthesia, St. Michael's Hospital in Toronto, and is an ISMP Canada fellow (2004-2005).

\section{References}

Cooper, J.B., R.S. Newbower and R.J. Kitz. 1984. "An Analysis of Major Errors and Equipment Failures in Anesthesia Management: Considerations for Prevention and Detection." Anesthesiology 60(1): 34-42.

Leape, L.L., D.M. Berwick and D.W. Bates. 2002. "What Practices Will Most Improve Safety? Evidence-Based Medicine Meets Patient Safety." Journal of the American Medical Association 288(4): 501-7.

Leape, L.L., T.A. Brennan, N.M. Laird, A.G. Lawthers, A.R. Localio, B.A. Barnes, L. Hebert, J.P. Newhouse, P.C. Weiler and H. Hiatt. 1991. "The Nature of Adverse Events in Hospitalized Patients. Results of the Harvard Medical Practice Study II." New England Journal of Medicine 324(6): 377-84.

Massachusetts Hospital Association. 1999. MHA Best Practice Recommendations to Reduce Medication Errors. Executive Summary. Burlington, MA: Massachusetts Coalition for the Prevention of Medical Errors. Retrieved April 30, 2006. <http://www.macoalition. org/documents/Best_Practice_Medication_Errors.pdf>.

Orser, B.A. 2000. "Medication Safety in Anesthetic Practice: First Do No Harm [Editorial].” Canadian Journal of Anesthesia 47(11): 1051-4.

Orser, B.A., R.J.B. Chen and D.A.Y. Yee. 2001. "Medication Errors in Anesthetic Practice: A Survey of 687 Practitioners." Canadian Journal of Anesthesia 48(2): 139-46.

Silver, M.P. and J.A. Antonow. 2000. "Reducing Medication Errors in Hospitals: A Peer Review Organization Collaboration." Joint Commission Journal on Quality Improvements 26(6): 332-40.

Webster, C.S., A.F. Merry, L. Larsson, K.A. McGrath and J. Weller. 2001. "The Frequency and Nature of Drug Administration Error during Anesthesia." Anaesthesia and Intensive Care 29(5): 494-500. 